Egyptian Journal of Aquatic Biology \& Fisheries

Zoology Department, Faculty of Science,

Ain Shams University, Cairo, Egypt.

ISSN $1110-6131$

Vol. 23(2): 585 - 597 (2019)

www.ejabf.journals.ekb.eg

\title{
The first data on the population parameters of the main fish species in man- made Lake Buyo (River Sassandra, Côte d'Ivoire)
}

\author{
Goli Bi B. E. P. ${ }^{1}{ }^{*}$, Kamelan T. M. ${ }^{1}$, Berté S. ${ }^{1}$, Kien K. B. ${ }^{2}$, \\ Ndiaye $S^{3}$ and Kouamelan E. P. ${ }^{1}$
}

1- Department of Biosciences, Felix Houphouet-Boigny University, Laboratory of Hydrobiology, 22 BP 582 Abidjan 22, Côte d'Ivoire;

2- Peleforo Gon Coulibaly University, BP 1328 Korhogo, Côte d'Ivoire

3 -Thiès University, National School of Agriculture (ENSA), BP A 296 Thiès, Sénégal

*Corresponding author: pacomegoli72@gmail.com

\section{ARTICLE INFO}

Article History:

Received: Dec. 13, 2018

Accepted: May 29, 2019

Online:June 2019

Keywords:

River Sassandra

Lake Buyo

Côte d'Ivoire

West Africa

Growth parameters

fishery management

\section{SUMMARY}

The growth parameters and the exploitation rate of the main 9 fish species found in the lake of the Buyo dam was studied from July 2017 to June 2018. The monthly frequency data for lengths obtained from experimental and commercial fisheries were analysed using the FiSAT II software and its sub-program ELEFAN for the evaluation of population parameters. The asymptotic length $\left(\mathrm{L}_{\infty}\right)$ varies from $63.33 \mathrm{~cm}$ for Chrysichthys nigrodigitatus to $15 \mathrm{~cm}$ for Synodontis koensis. The specific growth rate $(\mathrm{K})$ is higher $\left(0.9\right.$ year $\left.^{-1}\right)$ in Malapterurus electricus and lower $\left(0.21\right.$ year $\left.^{-1}\right)$ in the species Schilbe mandibularis, while the growth performance index $\left(\varphi^{\prime}\right)$ calculated from 3.48 in Chrysichthys nigrodigitatus to 2.04 in Tilapia zillii. The fishing mortality (F) and exploitation rate (E) calculated are below the optimal exploitation rate for most species. The recruitment pattern is a continuous model with a single peak and reveals a recruitment period in the months of May, June, August and October. According to the exploitation predictions, the species O. niloticus, $M$. electricus, C. nigrodigitatus, D. rostratus and $L$. niloticus have an exploitation rate E respectively $0.35 ; 0.46 ; 0.27 ; 0.41$ and 0.31 higher than the optimum exploitation rates Eop (respectively $0.29 ; 0.33 ; 0.37 ; 0.28$ and 0.27 ), which would mean that the stock of these species in the fishery is already reduced to more than $50 \%$ of its untapped biomass; therefore overexploited. Our study provides the first data on the population parameters of the main fish species from the Lake Buyo. These data could contribute to establish a sustainable management plan for fisheries resources only in lake Buyo.

\section{INTRODUCTION}

In Côte d'Ivoire, like in most developing countries, fish is the main source of animal protein (Ticheler, 2000). As a result, stocks of fish populations are decreasing due to extensive and uncontrolled exploitation of this animal resources (Lalèyè et al., 2007). Indeed, some fisheries have shifted from artisanal exploitation to industrial exploitation, from subsistence to commercial activity (Njiru et al., 2005, Kantoussan, 2007), resulting in dwindling catches observed in some fisheries, in the lakes Buyo 
(Vanga et al., 2002), Kossou (Da Costa and Konan, 2005), see their depletion (Vanga, 2004).

This situation today calls for the need to evaluate the influence of these pressures on the production of these lakeside systems. This means having knowledge of the composition of the catches, according to age or size, a more detailed description of the stock. In addition, growth and exploitation parameters are essential for a good understanding of general biology and population dynamics.

Lake Buyo is one of the most recent dam in Côte d'Ivoire after Lake Soubré in 2017. Since its creation, this lake has been the subject of several research projects (Traoré, 1996; Vanga, 2001; Vanga et al., 2002; Ossey et al., 2008 ; Kouamé, 2010). These works focused on the continental fisheries, the socioeconomic consequences of natural resource management, the impact of fishing on fish availability in the lakeside regions, the analytical study of chemical characteristics, and the biological diversity and dietary habits of some species. Previous work (Vanga, 2001; Kouamé, 2010) carried out on lake Buyo reported the predominance of Cichlidae and Claroteidae as well as that of Oreochromis niloticus, Tilapia sp. and Chrysichthys sp. in the catches from the Buyo Lake. The present study thus lays the foundations for the dynamics of the main fish population of the Buyo reservoir. There are many studies but there are currently no data available on the population dynamics of the species in this lake. It aims to estimate growth parameters and to assess the level of exploitation of the main species landed. The results of this work will contribute to the implementation of measures to better management of the stock and thus ensure the sustainability of this highly valued fishery resource in Côte d'Ivoire.

\section{MATERIALS AND METHODS}

\section{Study area}

The Lake of Buyo (Fig. 1) was built along the edge of the Tai National Park, 4 $\mathrm{km}$ downstream from the confluence of N'Zo and Sassandra, drowning approximately 8400 hectares of forest in the park (OIPR, 2006). According to Ossey et al. (2008), Lake Buyo occupies a catchment area of $46250 \mathrm{Km}^{2}$. This lake is between $06^{\circ} 14^{\prime}$ and $07^{\circ} 03^{\prime}$ north latitude and $06^{\circ} 54^{\prime}$ and $07^{\circ} 31^{\prime}$ west longitude and covers an area of $920 \mathrm{~km}^{2}$ (Kouamé, 2010).

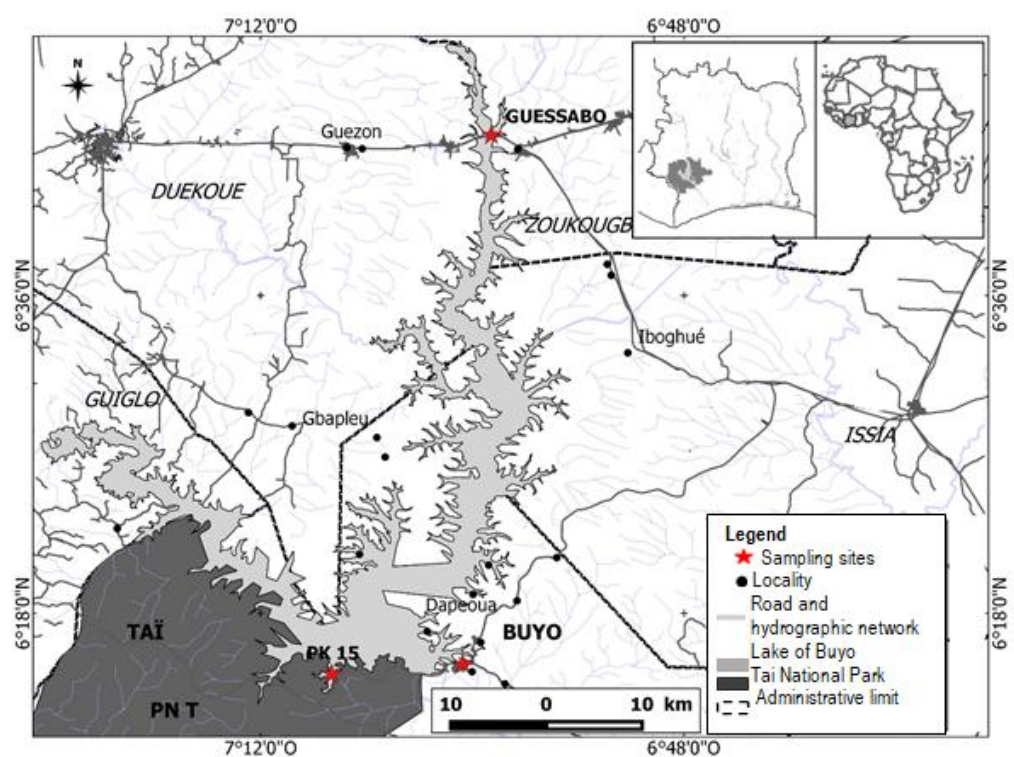

Fig. 1: Location of the Lake of Buyo and location of the sampling stations 
The hydrological regime of this lake depends on the Sassandra River, the N'Zo primary tributary and rainfall in the region (Traore and Konan, 1989). Three study stations such as Guessabo, Buyo city and PK15 have been selected in this study according to their proximity to the lake, the existence of a commercial exploitation of fish, their easy accessibility by road in all seasons.

Fish sampling and data collection

Sampling was carried out in three study stations (Guessabo, Buyo City and PK15) (Fig. 1). Fish were collected each month from July 2017 to June 2018. Specimens examined were from commercial and experimental fisheries. Commercial fish were caught using gillnets, seines and traps. Those from the experimental fishery were caught only with gillnets for a total of 3884 specimens. They were chosen on the basis of numerical abundance and were identified using dichotomous identification keys (Paugy et al., 2003a and b). On each specimen, the standard length expressed in $\mathrm{cm}$ was determined using an ichtyometer graduated.

Data processing

Determination of growth parameters $\left(\mathbf{L}_{\infty}, K, \varphi^{\prime}, \mathbf{R n}, \mathbf{t}_{\mathbf{0}}, \mathbf{T}_{\max }\right)$

Length was grouped into $1 \mathrm{~cm}$ intervals for small specimens and 2-4 cm for large specimens (Kantoussan, 2007; Tah, 2012) to allow for a representative number of individuals. Frequency distribution was analysed using FiSAT II software (Gayanilo et al., 2002). The FiSAT II ELEFAN I program was used to estimate the growth parameters $\left(\mathrm{L}_{\infty}\right)$ and $(\mathrm{K})$ according to the model of Von Bertalanffy (Gayanilo et al., 2002) which is as follows:

$\mathbf{L t}=L_{\infty}\left(1-\mathbf{e}^{-\mathbf{k}(\mathbf{t}-\mathbf{t 0})}\right)$

Where:

$\mathrm{Lt}=$ length of fish at age $\mathrm{t}$ considered $(\mathrm{cm}) ; \mathrm{L}_{\infty}=$ asymptotic length $(\mathrm{cm})$, length that the species could reach if it continues t0 live and grow indefinitely; $\mathrm{K}=$ growth coefficient or growth rate characterizing the speed with which the species grows towards $\mathrm{L}_{\infty}\left(\right.$ year $\left.^{-1}\right) ; \mathrm{t} 0=$ theoretical age of the fish when its length is zero (year). The parameter $t_{0}$ was obtained from the empirical equation of Pauly (1979):

$\log _{10}\left(-t_{0}\right)=-0.392-0.275 \log _{10} L_{\infty}-1.038 \log _{10} K$

The method consists of revealing the model of Length frequency distributions and validating the growth curves whose plots, overlapping with those of the distributions themselves, take into account the large number of this model. The distributions and the growth curves selected are then presented in the same graph.

The performance index $\left(\varphi^{\prime}\right)$ was evaluated from the growth parameters $\mathrm{L}_{\infty}$ and $\mathrm{K}$ by Pauly and Munro's relation (1984) which is defined as follows:

$$
\varphi^{\prime}=\log _{10} \mathbf{K}+2 \log _{10} \mathbf{L}_{\infty}
$$

The quality index of the adjustement $(\mathrm{Rn})$ was determined automatically by the FiSAT II software (Gayanilo et al., 2002).

Longevity or maximum age $\left(\mathrm{T}_{\max }\right)$ was calculated with Pauly's formula (1985):

$$
\mathbf{T}_{\max }=\mathbf{2 . 9 9 5 7} / \mathrm{k}
$$

Evaluation of the exploitation rate of the main species (Mortality, recruitment, yield, virtual populations).

\section{Mortality and exploitation rate}

The growth curve obtained was used to convert the length frequencies into age-class (Pauly, 1984) in order to determine the instantaneous mortality coefficients (M and F).

The instantaneous total mortality coefficient (Z) was estimated by the catch curve method according to the lengths used with the FiSAT II software with: 
$\mathbf{N}_{\mathrm{t}+1}=\mathbf{N}_{\mathrm{t}} \mathrm{e}^{-\mathrm{Z}}$

Where:

$\mathrm{Nt}=$ number of fish at time $\mathrm{t} ; \mathrm{Nt}+1=$ number of fish at time $\mathrm{t}+1$

The construction of this catch curve took into account $\mathrm{L}_{\infty}, \mathrm{K}, \mathrm{t}_{0}\left(\mathrm{t}_{0}=0\right)$ and the mean annual temperature $\left(\mathrm{T}^{\circ} \mathrm{C}\right)$ for the plot of a graph with Log Nt in ordinate, $\mathrm{t}$ in abscissa and $\mathrm{Z}=-\mathrm{b}$ the slope of the regression line, according to the following formula:

Where:

$$
\log N_{t}=a+b t
$$

$\mathrm{Nt}=$ number of individuals in length class $\mathrm{t}$; $\mathrm{a}=$ intercept at the origin of the regression line;

$\mathrm{b}=$ slope of the regression line

The final $(\log \mathrm{Nt})$ graph gives the instantaneous mortality rates $(\mathrm{Z}, \mathrm{M}$ and $\mathrm{F})$ and exploitation rates $(\mathrm{E})$.

The natural mortality (M) was calculated using the method of Pauly (1980) which is based on the following facts: there is obviously an inverse relationship between $\mathrm{M}$ and the maximum length observed itself partly related to longevity and $\mathrm{K}$ coefficient. This relationship is however not close enough to allow only an evaluation of M. This is why Pauly (1980) introduced the notion of average annual temperature of the medium. The equation is:

\section{$\log _{10} M=-0.0066-0.0279 \log _{10} L_{\infty}+0.6543 \log _{10} K+0.463 \log _{10} T$}

Where :

$\mathrm{T}=$ average annual temperature of the medium. In this study, the calculated annual temperature is $30.3^{\circ} \mathrm{C}$ (Obs. Person.)

According to Pauly (1980), this method of estimating $M$ is widespread in tropical regions.

Knowing $\mathrm{Z}$ and $\mathrm{M}$, the fishing mortality coefficient $(\mathrm{F})$ was obtained by difference $(\mathbf{F}=\mathbf{Z}-\mathbf{M})$ and the exploitation rate (E) which is the $\mathbf{F} / \mathbf{Z}$ ratio $[\mathbf{E}=\mathbf{F} / \mathbf{Z}=\mathbf{F} /(\mathbf{F}+\mathbf{M})]$ was also determined. The exploitation rate indicates whether the stock is slightly $(\mathrm{E}<0.5)$ or highly $(\mathrm{E}>0.5)$ exploited, under the assumption that the exploitation of the stock is optimal when $\mathrm{F}=\mathrm{M}$ or $\mathrm{E}=0.5$ (Gulland, 1971).

The Chi-square test was used here to compare the fishing mortality coefficients to the theoretical value 1 .

\section{Recruitment period}

Using the growth parameters $\mathrm{L}_{\infty}, \mathrm{K}$ and $\mathrm{t}_{0}$, another program of FiSAT II (version 1.2.2) to reconstructs a relative frequency histogram of births for each month. This graph, which shows the monthly changes in the recruitment of young fish, was obtained by retro projection of length-frequency data along the time axis (Moreau and Cuende, 1991). The normal distribution of the recruitment pattern was determined by NORMSEP (Pauly and Caddy, 1985) in FiSAT II.

\section{Yield and biomass per recruit}

The reference points of Beverton and Holt (1966) for optimal fisheries management are $\mathrm{E}_{0.1} ; \mathrm{E}_{0.5}$ and $\mathrm{E}_{\max }$ represented on the curves of variation of the relative yield ( $\mathrm{Y}$ '/ R) and relative biomass per recruit $\left(\mathrm{B}^{\prime} / \mathrm{R}\right)$. These different exploitation rates are respectively defined as being: (1) the exploitation rate for which the marginal increase in the relative yield per recruit is $1 / 10$ or $10 \%$ of its value; (2) the exploitation rate that results in a reduction of the untapped stock biomass by $50 \%$ and (3) the exploitation rate that produces a maximum yield per recruit $\left(\mathrm{E}_{\max }\right)$. 


\section{Virtual Population Analysis (VPA)}

Virtual population analysis are methods that allow the population to be reconstructed from total catch data according to age or length. VPA was performed uing FiSAT II with the aid of modified Jones and Van Zalinge (1981) routine adapted to length frequencies.

\section{RESULTS}

\section{Growth parameters}

The growth parameters and maximum length captured for the main nine fish species from the lake of Buyo are shown in Table 1. The estimated growth curves for these species are shown in Fig. 2. It can be seen that the maximal length observed for the nine species is all less than their respective asymptotic length $\left(\mathrm{L}_{\infty}\right)$. Therefore, it is observed that within the same genus the value of $\mathrm{L}_{\infty}$ is closer, in Cichlidae except in Oreochromis niloticus.

Table 1: Growth parameters of the main fish species from Buyo Lake from July 2017 to June 2018. n $=$ number of specimens.

\begin{tabular}{|c|c|c|c|c|c|c|c|c|c|}
\hline Parameters & $\begin{array}{c}\text { Oreochromis } \\
\text { niloticus } \\
(\mathrm{n}=\mathbf{8 1 9})\end{array}$ & $\begin{array}{c}\text { Chrysichthys } \\
\text { nigrodigitatus } \\
(\mathrm{n}=798)\end{array}$ & $\begin{array}{c}\text { Synodontis } \\
\text { koensis } \\
(n=474)\end{array}$ & $\begin{array}{c}\text { Distichodus } \\
\text { rostratus } \\
(\mathrm{n}=342)\end{array}$ & $\begin{array}{c}\text { Malapterurus } \\
\text { electricus } \\
(\mathbf{n}=\mathbf{3 1 4})\end{array}$ & $\begin{array}{c}\text { Tilapia } \\
\text { zillii } \\
(\mathrm{n}=\mathbf{2 8 1})\end{array}$ & $\begin{array}{c}\text { Lates } \\
\text { niloticus } \\
(\mathrm{n}=\mathbf{2 7 5})\end{array}$ & $\begin{array}{c}\text { Schilbe } \\
\text { mandibularis } \\
(\mathrm{n}=279)\end{array}$ & $\begin{array}{c}\text { Tilapia } \\
\text { hybrid } \\
(\mathrm{n}=\mathbf{3 0 2})\end{array}$ \\
\hline $\begin{array}{l}\text { LS max obs } \\
(\mathrm{cm})\end{array}$ & 29.5 & 57 & 13.5 & 24.5 & 28.5 & 17 & 36 & 26.5 & 17 \\
\hline $\mathbf{L}_{\infty}(\mathbf{c m})$ & 32.77 & 63.33 & 15 & 27.22 & 31.66 & 18.88 & 40 & 29.44 & 18.88 \\
\hline K $\left(\right.$ year $\left.^{-1}\right)$ & 0.6 & 0.76 & 0.63 & 0.61 & 0.9 & 0.31 & 0.5 & 0.21 & 0.8 \\
\hline$\varphi^{\prime}$ & 2.81 & 3.48 & 2.15 & 2.65 & 2.95 & 2.04 & 2.9 & 2.26 & 2.45 \\
\hline $\mathbf{R n}$ & 0.3 & 0.26 & 0.45 & 0.74 & 0.3 & 0.32 & 0.34 & 0.35 & 0.25 \\
\hline$t_{0}$ (year) & -0.26 & -0.17 & -0.31 & -0.57 & -0.17 & -0.61 & -0.3 & -0.8 & -0.22 \\
\hline $\mathbf{T}_{\max }($ year $)$ & 5 & 4 & 5 & 5 & 4 & 10 & 6 & 15 & 4 \\
\hline
\end{tabular}

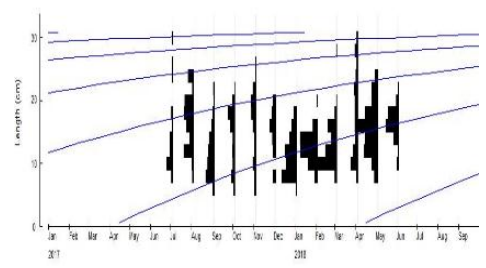

Oreochromis niloticus
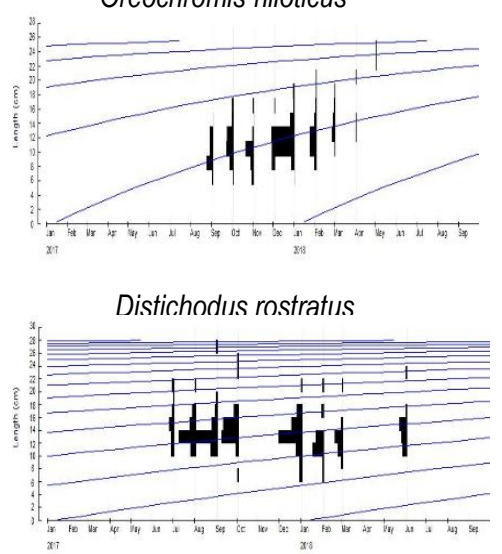

Schilbe mandibularis

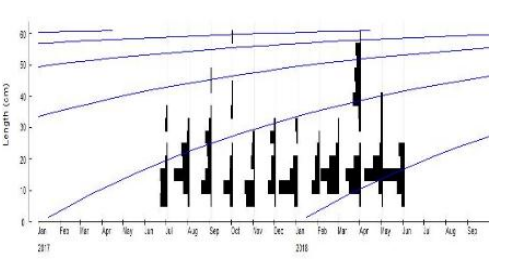

Chrysichthys nigrodigitatus

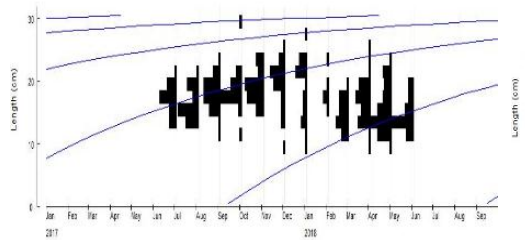

Malapterurus electricus

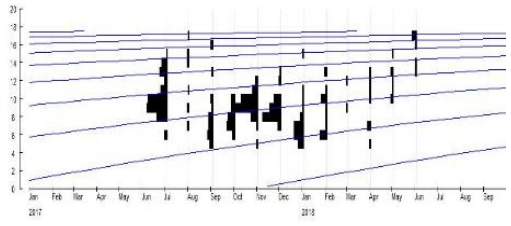

Tilapia zillii

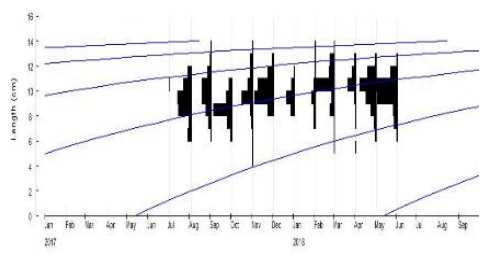

Synodontis koensis

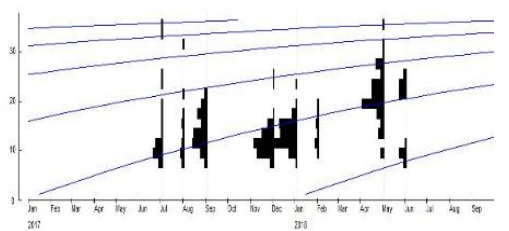

Lates niloticus

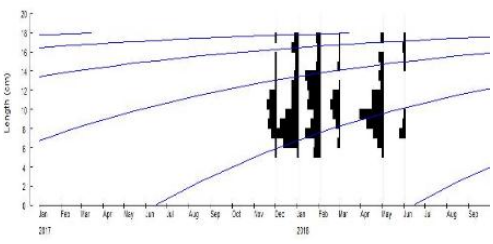

Tilapia hybrid

Fig. 2: Modeling of growth of the main fish species from Buyo Lake according to Von Bertalanffy model. In black: the positive value of the frequencies observed and theoretical sizes; blue lines overlapping on lenght frequency histograms: growth curves indicating cohorts. 
The growth performance index $\left(\varphi^{\prime}\right)$ is relatively high in this species. The specific growth rate $(\mathrm{K})$ is higher in the species Malapterurus electricus (0.9 year $\left.{ }^{-1}\right)$, Tilapia hybrid $\left(0.8\right.$ year $\left.^{-1}\right)$ and Chrysichthys nigrodigitatus $\left(0.76\right.$ year $\left.^{-1}\right)$. Of the nine species, $C$. nigrodigitatus has the highest growth performance $\left(\varphi^{\prime}\right)$ while the other species have a performance index which is in the same range. When the theoretical age of the fish at length zero $\left(\mathrm{t}_{0}\right)$ is high, its longevity (or $\mathrm{T}_{\max }$, maximum age) is shorter. This is the case for most species, except for Tilapia zillii and Schilbe mandibularis, which have a low $\mathrm{t}_{0}(-0.61$ and -0.8 year) with a high longevity (10 and 15 years).

\section{Exploitation parameters}

\section{Instantaneous coefficient of mortality and exploitation rate}

The catch curves according to the lengths obtained from the different populations studied are illustrated in Fig. 3.
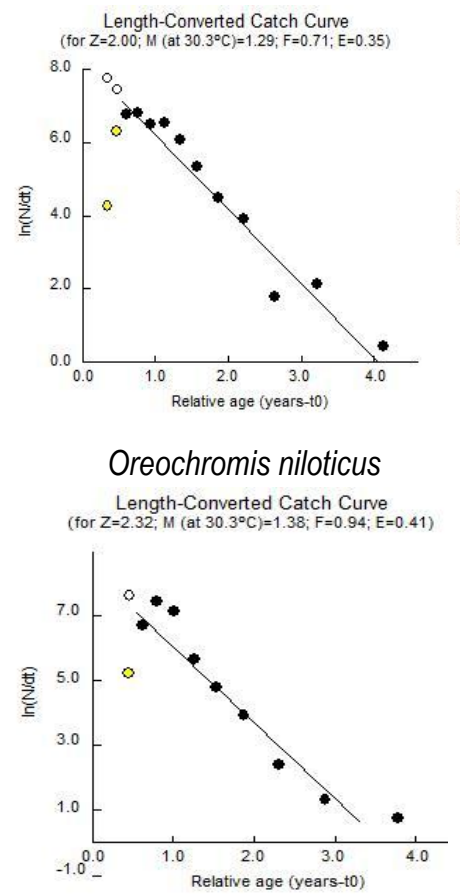

Distichodus rostratus

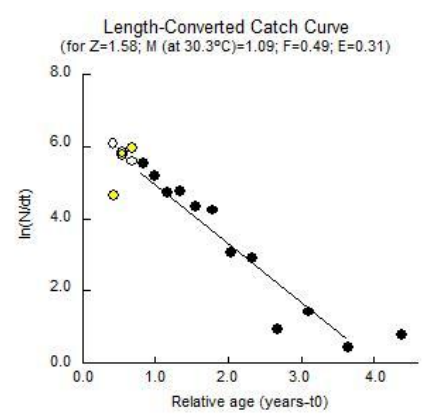

Lates niloticus

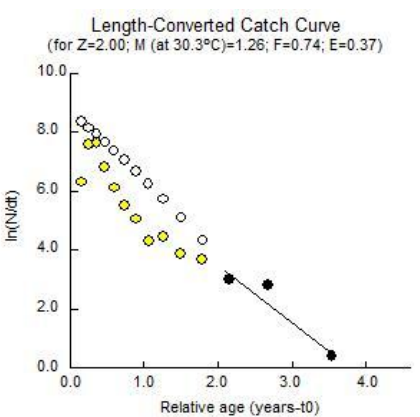

Chrysichthys nigrodigitatus

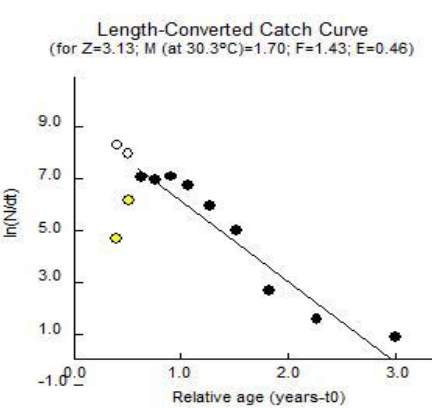

Malapterurus electricus

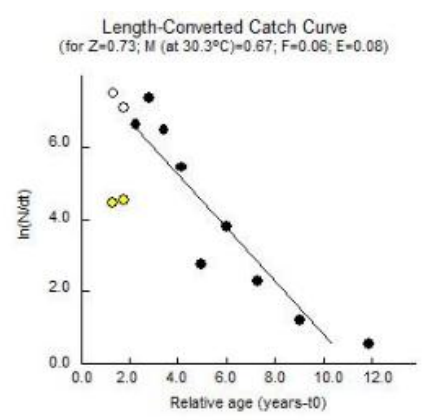

Schilbe mandibularis

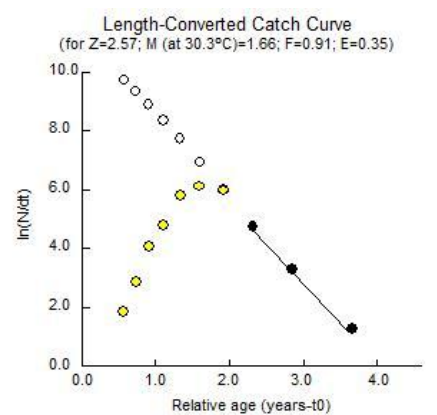

Synodontis koensis

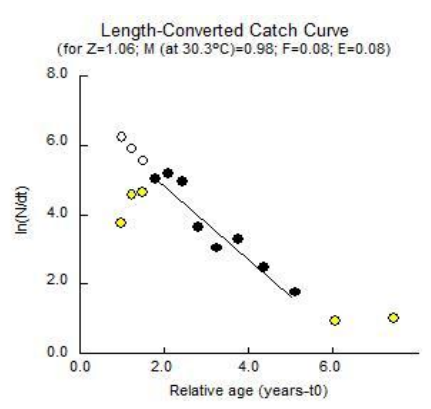

Tilapia zillii

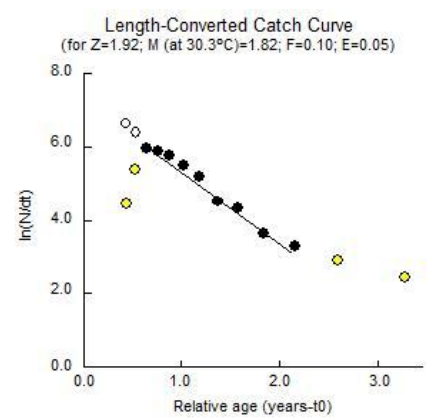

Tilapia hybrid

Fig. 3: Linear catch curve of the main species from the Lake of Buyo. The black dots are those used for calculating $(Z)$ through a least squares linear regression; the yellow dots are not taken into account either too close or too far from the asymptotic length; and the white dots are the extrapolated points of the curve according to the lengths.

The values of the total mortality $(\mathrm{Z})$, the natural mortality $(\mathrm{M})$ at the average temperature of $30.30{ }^{\circ} \mathrm{C}$, the fishing mortality $(\mathrm{F})$ and the exploitation rates of the 
nine main fish species are shown in Table 2. For all the species studied, the natural mortality coefficients (M) are greater than their respective fishing mortality coefficients (F). Natural mortality (M) is, however, higher in Tilapia hybrid (1.82 per year) and lower in $S$. mandibularis ( 0.67 per year). The fishing mortality $(\mathrm{F})$ is 1.43 per year in M. electricus. In addition, this species has the highest total mortality rate (Z) (3.13 per year). However, the species S. koensis and D. rostratus have a fishing mortality coefficient very close to 1 ( $\mathrm{p}>0.05$, chi-square test) with their relatively high $\mathrm{Z}$ respectively 2.57 and 2.32 per year. As for the exploitation rate (E), it is closer to the theoretical value 0.5 for $D$. rostratus species $(0.41)$ and $M$. electricus species (0.46).

\section{Recruitment}

The histograms (Fig. 4) show the monthly changes in the recruitment intensity of juveniles fish of the main species entering the lake of Buyo. The appearance of young fish in the water body is regular and year-round in this lake reaching a maximum level in October for O. niloticus, April for $C$. nigrodigitatus, May for $S$. koensis and L. niloticus, June for D. rostratus and T. hybrid, August for $M$. electricus, T. zillii and S. mandibularis.

Table 2: Exploitation parameters of the main fish species from Lake Buyo from July 2017 to June 2018. $\mathrm{n}=$ number of specimens

\begin{tabular}{|c|c|c|c|c|c|c|c|c|c|}
\hline Parameters & $\begin{array}{c}\text { Oreochromis } \\
\text { niloticus } \\
(\mathrm{n}=\mathbf{8 1 9})\end{array}$ & $\begin{array}{c}\text { Chrysichthys } \\
\text { nigrodigitatus } \\
(\mathrm{n}=798)\end{array}$ & $\begin{array}{c}\text { Synodontis } \\
\text { koensis } \\
(n=474)\end{array}$ & $\begin{array}{c}\text { Distichodus } \\
\text { rostratus } \\
(\mathrm{n}=342)\end{array}$ & $\begin{array}{c}\text { Malapterurus } \\
\text { electricus } \\
(\mathbf{n}=314)\end{array}$ & $\begin{array}{c}\text { Tilapia } \\
\text { zillii } \\
(\mathrm{n}=\mathbf{2 8 1})\end{array}$ & $\begin{array}{c}\text { Lates } \\
\text { niloticus } \\
(\mathrm{n}=275)\end{array}$ & $\begin{array}{c}\text { Schilbe } \\
\text { mandibularis } \\
(\mathrm{n}=279)\end{array}$ & $\begin{array}{c}\text { Tilapia } \\
\text { hybrid } \\
(\mathrm{n}=302)\end{array}$ \\
\hline M (year $\left.{ }^{-1}\right)$ & 1.29 & 1.26 & 1.66 & 1.38 & 1.7 & 0.98 & 1.09 & 0.67 & 1.82 \\
\hline F (year $\left.{ }^{-1}\right)$ & 0.71 & 0.74 & 0.91 & 0.94 & 1.43 & 0.08 & 0.49 & 0.06 & 0.1 \\
\hline $\mathrm{Z}\left(\right.$ year $\left.^{-1}\right)$ & 2 & 2 & 2.57 & 2.32 & 3.13 & 1.06 & 1.58 & 0.73 & 1.92 \\
\hline E & 0.35 & 0.37 & 0.35 & 0.41 & 0.46 & 0.08 & 0.31 & 0.08 & 0.05 \\
\hline
\end{tabular}

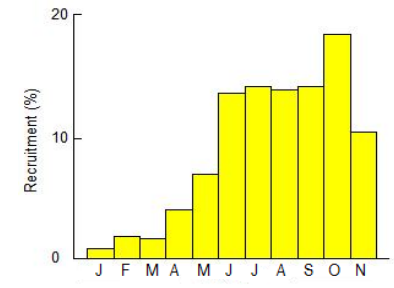

Oreochromis niloticus

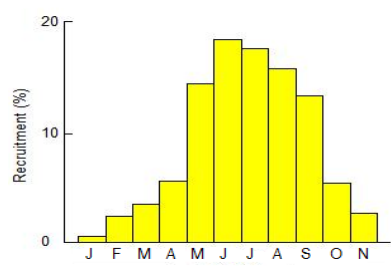

Distichodus rostratus

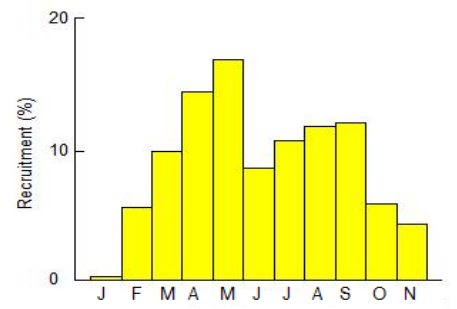

Lates niloticus

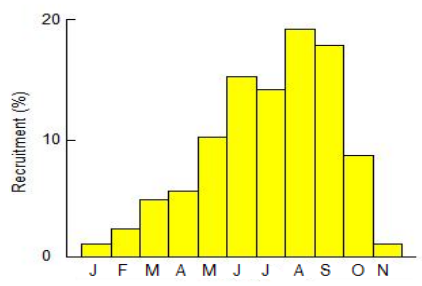

Malabterurus electricus

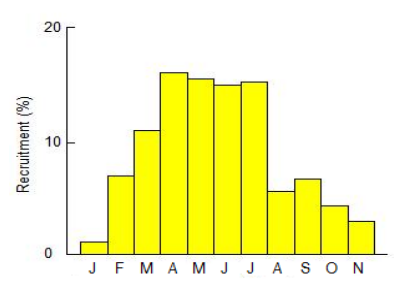

Chrysichthys nigrodigitatus

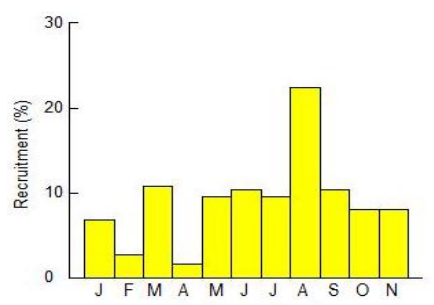

Schilbe mandibularis

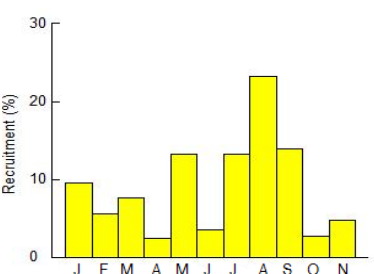

Tilapia zillii

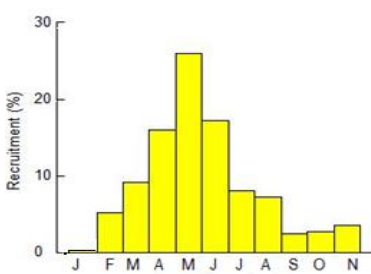

Synodontis koensis

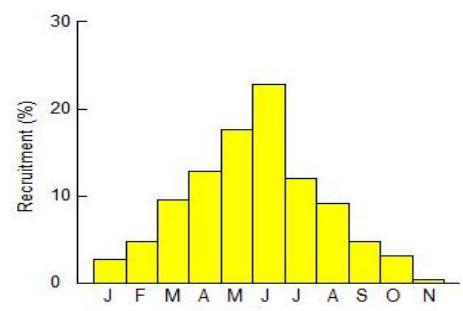

Tilapia hybrid

Fig. 4: Recruitment model of the main species from the Lake of Buyo 


\section{Relative yield ( $\left.\mathbf{Y}^{\prime} / \mathbf{R}\right)$ and relative biomass per recruit $\left(\mathbf{B}^{\prime} / \mathbf{R}\right)$}

The relative yield curves $\left(\mathrm{Y}^{\prime} / \mathrm{R}\right)$ and relative biomass per recruit $\left(\mathrm{B}^{\prime} / \mathrm{R}\right)$ for fixed values of Lc / L $\infty$ and $\mathrm{M} / \mathrm{K}$ are plotted using the FiSAT II software and allowed the determination of the biological references points for the fish populations studied (Table 3). This table shows that the optimal exploitation rate $\left(\mathrm{E}_{0.5}\right)$ of $O$. niloticus $\left(\mathrm{E}=0.35>\quad \mathrm{E}_{0.5}=0.29\right), \quad M$. electricus $\left(\mathrm{E}=0.46>\mathrm{E}_{0.5}=0.33\right), C$. nigrodigitatus $\left(\mathrm{E}=0.37>\mathrm{E}_{0.5}=0.27\right)$, D. rostratus $\left(\mathrm{E}=0.41>\mathrm{E}_{0.5}=0.28\right)$ and $L$. niloticus $\left(\mathrm{E}=0.31>\mathrm{E}_{0.5}=0.27\right)$ is reached. Fig. 5 shows for the 9 main species of fish exploited from the lake of the Buyo dam, the plotting of $\mathrm{Y}^{\prime} / \mathrm{R}$ on $\mathrm{E}(=\mathrm{F} / \mathrm{Z})$ and $\left(\mathrm{B}^{\prime} / \mathrm{R}\right.$ ) on $\mathrm{E}$, which allow the estimation of $\mathrm{E}_{\max }, \mathrm{E}_{0.1}$ and $\mathrm{E}_{0.5}$ biological reference points.

Table 3: Summary of the analysis of the relative yield per recruit of the main fish species exploited from the Lake of Buyo.

\begin{tabular}{lcccccc}
\hline \multicolumn{1}{c}{ Species } & \multicolumn{7}{c}{ Exploitation rate } \\
\cline { 2 - 7 } & $\mathbf{L}_{\mathbf{c}} / \mathbf{L}_{\infty}$ & $\mathbf{M} / \mathbf{K}$ & $\mathbf{E}_{\mathbf{0 , 1}}$ & $\mathbf{E}_{\mathbf{0 , 5}}$ & $\mathbf{E}_{\mathbf{m a x}}$ & $\mathbf{E}=\mathbf{F} / \mathbf{Z}$ \\
\hline Oreochromis niloticus & 0.25 & 2.15 & 0.41 & $\mathbf{0 . 2 9}$ & 0.49 & $\mathbf{0 . 3 5}$ \\
Synodontis koensis & 0.57 & 2.63 & 1 & 0.40 & 1 & 0.35 \\
Malapterurus electricus & 0.38 & 1.88 & 0.52 & $\mathbf{0 . 3 3}$ & 0.61 & $\mathbf{0 . 4 6}$ \\
Chrysichthys nigrodigitatus & 0.17 & 1.65 & 0.36 & $\mathbf{0 . 2 7}$ & 0.44 & $\mathbf{0 . 3 7}$ \\
Distichodus rostratus & 0.26 & 2.24 & 0.41 & $\mathbf{0 . 2 8}$ & 0.50 & $\mathbf{0 . 4 1}$ \\
Lates niloticus & 0.19 & 2.18 & 0.36 & $\mathbf{0 . 2 7}$ & 0.44 & $\mathbf{0 . 3 1}$ \\
Schilbe mandibularis & 0.33 & 3.19 & 0.51 & 0.32 & 0.64 & 0.08 \\
Tilapia hybride & 0.34 & 2.27 & 0.45 & 0.31 & 0.59 & 0.05 \\
Tilapia zillii & 0.36 & 3.16 & 0.56 & 0.33 & 0.70 & 0.08 \\
\hline
\end{tabular}

In bold: species with an exploitation rate $\mathrm{E}$ close to the optimal exploitation rate $\mathrm{E}_{0.5}$ or the maximum exploitation rate $\mathrm{E}_{\max }$

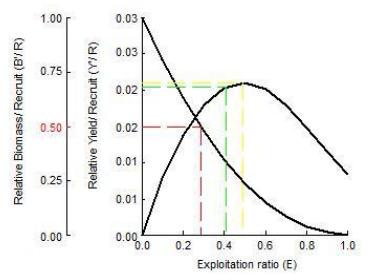

Oreochromis niloticus

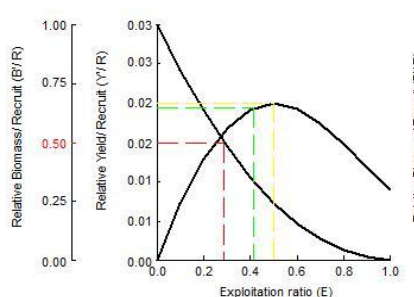

Distichodus rostratus

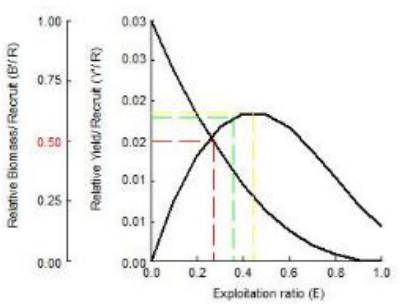

Lates niloticus

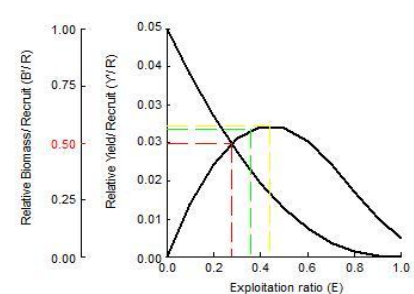

Chrvsichthvs niarodiaitatus

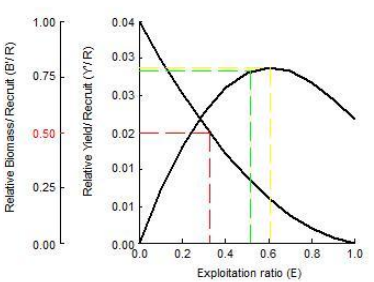

Malapterurus electricus

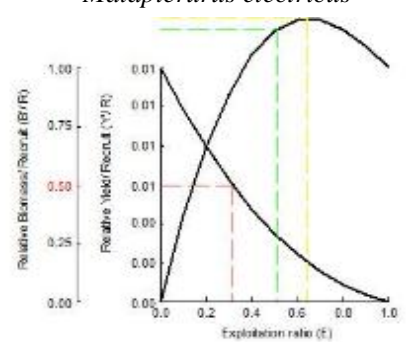

Schilbe mandibularis

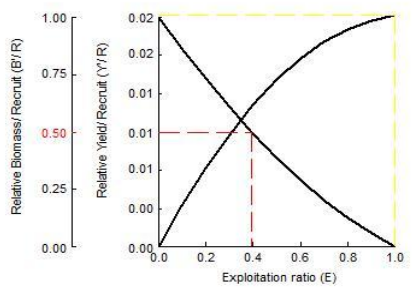

Synodontis koensis

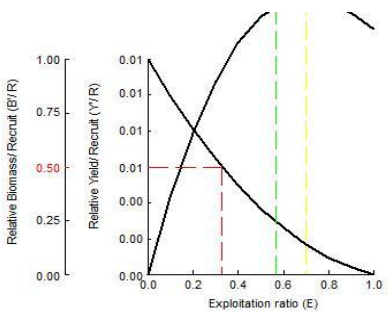

Tilapia zillii

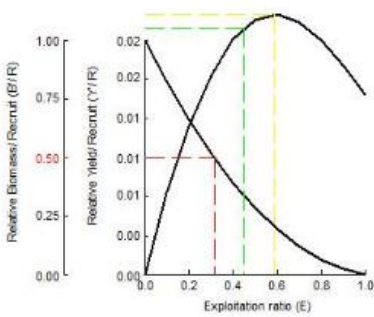

Tilapia hybrid

Fig. 5: Curve showing the variation in relative yield per recruit ( $\left.Y^{\prime} / \mathrm{R}\right)$ and relative biomass per recruit $\left(\mathrm{B}^{\prime} / \mathrm{R}\right)$ as a function of the exploitation rate $\mathrm{E}$ for the main populations exploited from the Lake of Buyo. 


\section{Virtual population analysis}

The growth and exploitation parameters made it possible to establish the histograms of the virtual populations of the 9 main species of fish from the lake at the Buyo dam using FiSAT (Fig. 6). According to the reconstruction of the population represented in Fig. 6, it appears that the lost due to natural causes are higher in juveniles than in the adult population.

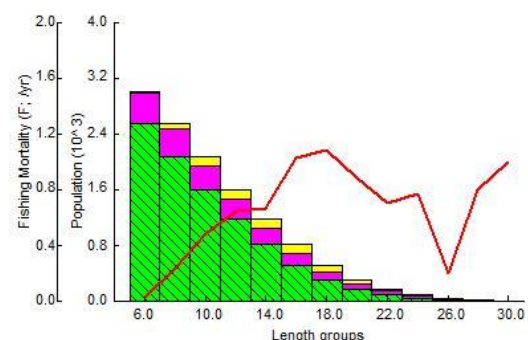

Oreochromis niloticus

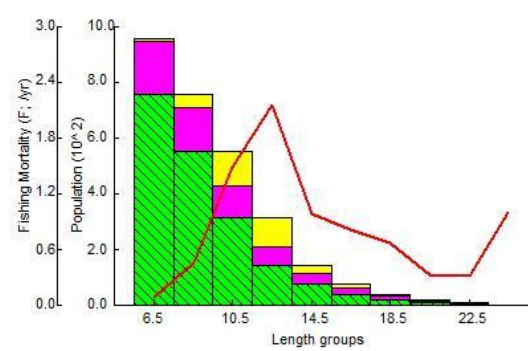

Distichodus rostratus

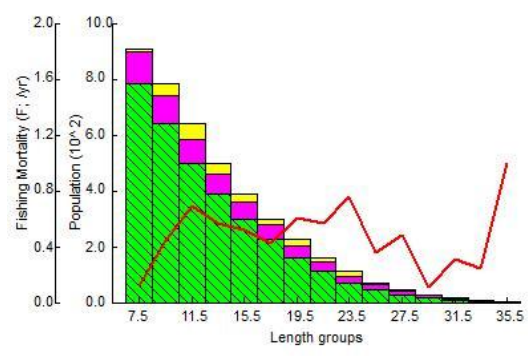

Lates niloticus

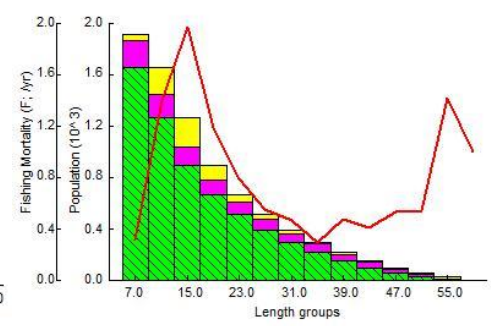

Chrysichthys nigrodigitatus

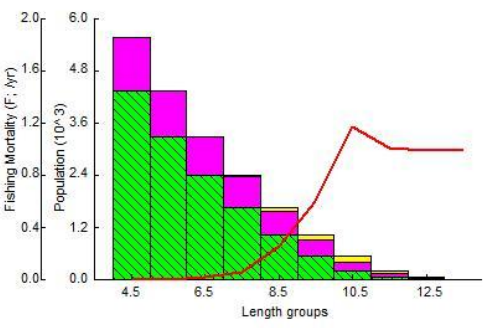

Synodontis koensis

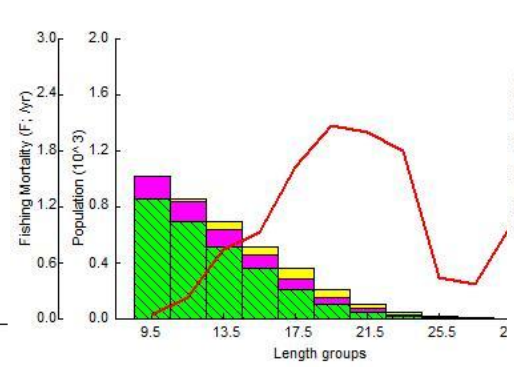

Malapterurus electricus

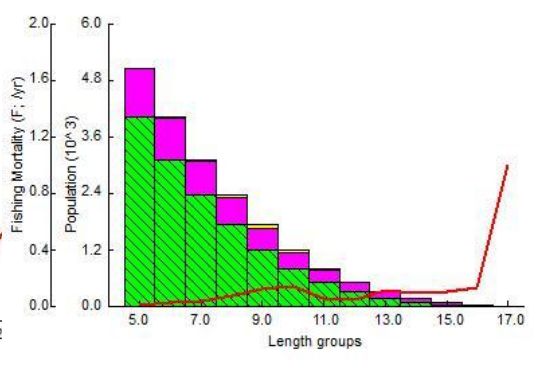

Tilapia zillii

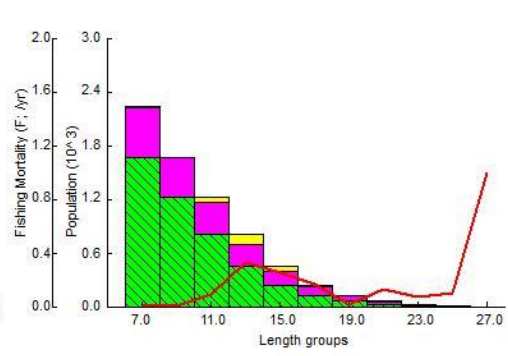

Schilbe mandibularis

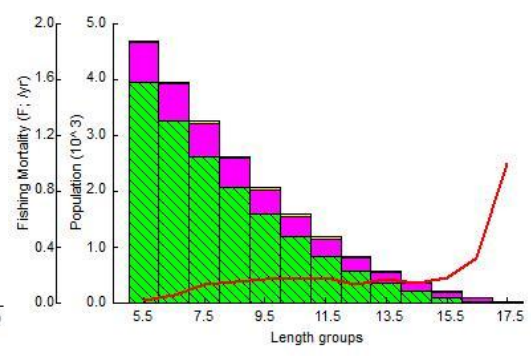

Tilapia hybrid

Fig. 6: Histograms of virtual populations based on the length of the main fish species landed at Lake of Buyo. In green: survivors; in pink: natural losses; in yellow: losses by catch; pink line: fishing mortality

As for the one lost to catches, it is more found in individuals of length between 10 and $18 \mathrm{~cm}$ for $O$. niloticus; 11 and $19 \mathrm{~cm}$ for C. nigrodigitatus; 9.5 and $10.5 \mathrm{~cm}$ for S. koensis; 10.5 and $12.5 \mathrm{~cm}$ for D. rostratus; 13.5 and 19.5 for M. electricus; 9 and $10 \mathrm{~cm}$ for T. zillii; 9.5 and $15.5 \mathrm{~cm}$ for L. niloticus; 12 and $15 \mathrm{~cm}$ for $S$. mandibularis; virtually absent in T. hybrid. The analysis of the graph reveals that the highest fishing mortality rate $(\approx 1.1 /$ year) would be observed for fish of length between 17 and $18 \mathrm{~cm}$ for $O$. niloticus; 13 and $15 \mathrm{~cm}$ with a rate of about 2 / year for C. nigrodigitatus; 10 and $10.5 \mathrm{~cm}$ with a rate of about 1.2 / year for S. koensis; 11.5 and $12.5 \mathrm{~cm}$ with a rate of about 2.1 / year for D. rostratus; 18.5 and $19.5 \mathrm{~cm}$ with a 
rate of about 2.1 / year for M. electricus; 22.5 and $23.5 \mathrm{~cm}$ with a rate of about 0.7 / year for L. niloticus

\section{DISCUSSION}

The majority of maximum lengths (LS) measured in species from the Lake of Buyo are less than the value of the asymptotic length $\left(\mathrm{L}_{\infty}\right)$. This means that the fish is caught before reaching their infinite length. This observation is confirmed by the small number of bigger sizes. The $\mathrm{L}_{\infty}$ values of the fish species studied from Lake Buyo are higher than those obtained by Tah et al. (2010) in Lake Ayamé I in Côte d'Ivoire, Niyonkuru et al. (2003) in Lake Nokoué in Benin, Baijot and Moreau (1997) in the Tanguiga reservoir in Burkina Faso for species such as Chrysichthys nigrodigitatus (63.33 $\mathrm{cm}$ in Buyo, $46 \mathrm{~cm}$ in Ayamé $\mathrm{I}, 26 \mathrm{~cm}$ in Nokoué) Oreochromis niloticus (32.77 $\mathrm{cm}$ in Buyo, $17.6 \mathrm{~cm}$ in Tanguiga), Schilbe mandibularis (29.44 cm in Buyo, $29 \mathrm{~cm}$ in Ayamé I). However, higher $\mathrm{L}_{\infty}$ values $(35.5 \mathrm{~cm})$ were observed by Tah et al. (2010) for O. niloticus in Ayamé Lake I. Abowei and Hart (2007) deduced that the observed differences in maximum Length in C. nigrodigitatus in Nigeria's lower rivers is due to overexploitation, environmental pollution and fishery degradation. In our case, this variation is due to overexploitation and natural predation.

In addition, the calculated growth performance index $\left(\varphi^{\prime}\right)$ of $O$. niloticus, $D$. rostratus, $M$. electricus and $L$. niloticus are $2.81 ; 2.65 ; 2.95$ and 2.90 respectively. These values are in the range $\left(2.65<\varphi^{\prime}<3.32\right)$ proposed by Baijot and Moreau (1997) for African fish. For these authors, such performance index values are attributed to reputable stocks of tropical slow-growing fish. O. niloticus and $C$. nigrodigitatus show the highest growth performance index $(2.81,3.48)$ compared to those reported for the same species $(2.78,2.71)$ in Lake Ayamé I, in Nigeria and Benin $(3.10,3.29$, 2.95 respectively) for $C$. nigrodigitatus. According to Tah et al. (2010), a rapid growth rate reveals a defensive mechanism against predators.

Natural mortality of major species is higher than fishing mortality. These results indicate that stocks of these species are more affected by natural predation than by fishing. This trend has also been observed by Tah et al. (2010) at Lake Ayamé I and Abowei and Davies (2009) in the lower river in the Niger Delta in Nigeria. In addition, the $\mathrm{M} / \mathrm{K}$ value greater than 2 for some species confirms the preponderance of natural predation as a key factor in the high natural mortality observed (Moreau et al., 2006). This trend was reported by Villanueva (2004) in four other African waters (Sine Saloum in Senegal, Gambia estuary, Nokoué lagoons and Ebrié). The exploitation rate values $(\mathrm{E})$ are below the optimum exploitation rate $\left(\mathrm{E}_{\mathrm{op}}\right.$ $=0.5$ ) recommended by Gulland (1971). These results showed that the main species found in the Lake Buyo appear to be underexploited. These results are consistent with those of Tah (2012) in Lake Ayamé I with the exception of Schilbe mandibularis, which is overexploited in Lake Ayamé I. In addition, in species $O$. niloticus, M. electricus , C. nigrodigitatus, D. rostratus and L. niloticus, the current exploitation rates $\mathrm{E}$ is higher than the optimum exploitation rates Eop calculated by FiSAT, which would mean that the stock of these species in the fishery is already reduced to more than $50 \%$ of its untapped biomass; therefore overexploited.

Regarding recruitment, the peak recruitment (period of the predominance of juvenile specimens in the year) in these species is observed in April, May, June, August and October,. Indeed, this phenomenon occurs during the rainy season when trophic conditions become favorable for the growth of young fish (Koné, 2000). 
These results are similar to those of Tah et al. (2010) and the work of several authors who have worked on tropical fish reproduction in Africa (Koné, 2000; Ouattara et al., 2008).

As for the virtual analysis of the populations, it shows that the mortality natural rate decreases progressively as the size of the fish increases. This could be explained by the fact that juveniles are more vulnerable to natural predation as indicated by Koné (2000).

Considering the results of this study, we recommend reducing fishing effort from April to June and from August to October, period where the recruitment of juveniles fishes into Buyo dam lake is very intense. Furthemore, this work draws attention to the need to focus in particular on the monitoring of species $O$. niloticus, C. nigrodigitatus, L. niloticus, M. electricus and D. rostratus whose the stocks in the fishery were already reduced by more than $50 \%$ of the unexploited biomass.

\section{ACKNOWLEDGEMENT}

The authors sincerely thank the Directorate of Aquaculture and Fisheries (DAP), the Support Program for the Sustainable Management of Fisheries Resources (PAGDRH) and the Félix Houphouët-Boigny University (UFHB) who financially assisted this work. We also thank Mr Kouassi Henry Delmas, Lieutenants Kamagaté Beman and N'Guessan Kouadio Gontran (head of the fishing station of Buyo and Guessabo respectively) and the fishermen who assisted in the data collection in the field.

\section{REFERENCES}

Abowei, J.F.N. and Hart, A. (2007). Size, Composition, age, growth, mortality and exploitation rate of Chrysichthys nigrodigitatus from Nun River, Niger Delta, Nigeria. Afr. Journal of Applied Zoology and Environmental Biology, 9: 4450.

Abowei, J.F.N. and Davies, O.A. (2009). Some population parameters of Clarotes Laticeps (Ruppell, 1829) from the Fresh Water Reaches of Lower Nun River, Niger Delta Nigeria. American Journal of Scientific Research, 2: 15-19.

Baijot, E. and Moreau, J. (1997). Biology and demographic status of the main fish species in the reservoirs of Burkina Faso. Hydrological Aspects of Fisheries in Small Reservoirs in Sahel Region. Technical Centre for Agricultural and Rural Cooperation, Commission of the European Communities, Wageningen, Netherlands,pp. 79-109.

Beverton, R.J.H. and Holt S.J. (1966). Manuel of methods for fish sock assessment. Part 2. Tables of yield functions. FAO Fisheries Technical Papers, $67 \mathrm{pp}$.

Da Costa, K.S. and Konan, K.F. (2005). Lac Kossou : Potentiel halieutique et Modalités d'un développement durable de la pêche. FAO/PMEDP, Projet Pilote Pêche Kossou GCP. INT/735/UK, Rapport d'Expertise, 200 p.

Gayanilo, F.C. Jr; Sparre, P. and Pauly, D. (2002). The FAO-ICLARM Stock Assessment Tools II (FiSAT II ver. 1.2.2). FAO, Rome. Available at: http://www.fao.org/fi/statist/fisoft/fisat/]. (last accessed 02 February 2006).

Gulland, J.A. (1971). The fish resources of the oceans. West by the fleet, Survey. Fishing News Books, Ltd., Surrey, (England), 225 pp. 
Jones, R. and Van Zalinge, N.P. (1981). Estimations of mortality rate and population size for shrimp in Kuwait waters. Kuwait Bulletin of Marine Science; 2: 273288.

Kantoussan, J. (2007). Impact de la pression de pêche sur l'organisation des peuplements de poissons : Applications aux retenues artificielles de Sélingué et de Manantali, Mali Afrique de l'Ouest. Thèse de Doctorat: Mention halieutique Agrocampus de Rennes, France, 195 pp.

Koné, T. (2000). Régime alimentaire et reproduction d'un Tilapia lagunaire (Sarotherodon melanotheron melanotheron Rüppel, 1852) dans la rivière Bia et le lac de barrage d'Ayamé, Côte d'Ivoire). Thèse de Doctorat, Katholieke Universiteit, Leuven, $253 \mathrm{pp}$.

Kouamé, K.A. (2010). Diversité biologique et habitudes alimentaires de quelques espèces de poissons dans le cours inférieur du bassin du fleuve Sassandra (Côte d'Ivoire). Thèse de Doctorat. Université Cocody-Abidjan, Côte d'Ivoire, 219 pp.

Lalèyè, P. ; Akélé, D. and Philipart, J-C. (2007). La pêche traditionnelle dans les plaines inondables du fleuve Ouémé au Bénin. Cahier d'Ethologie; 22(2): 2538.

Moreau, J. and Cuende, F.X. (1991). On improving the resolution of the recruitment patterns of fishes. ICLARM Fishbyte, 9(1): 45-46.

Moreau, J.; Amarasinghe, U.S.; Sricharoen Dham, B.; Prabath, R.P.; Jayasinghe, K. and Villanueva, M.C. (2006). Population dynamic of commercially important fish species in four Asian reservoirs. In: Aquatic Ecosystems and development; Comparative Asian Perspectives (Schiemer F., Simon D., Amarasinghe U. S. \& Moreau J., eds), pp. 295-305.

Niyonkuru, C. ; Laleye, P. ; Villanueva, M. C. and Moreau, J. (2003). Population Parameters of Main Fish species of Lake Nokoue in Benin. Abstract. Third International Conference Pan African Fish and Fisheries Association, Cotonou, Benin, pp. 10-14 November 2003.

Njiru, M.; Waithaka, E.; Muchiri, M.; Van Knaap, M. and Cowx I.G. (2005). Exotic introductions to the fishery of Lake Victoria: What are the management options? Lakes \& Reservoirs: Research \& Management, 10(3): 147-155.

OIPR, (2006). Plan d'aménagement et de gestion du Parc National de Taï, 99 pp.

Ossey, B.Y.; Mambo, V.; Abiba, S.T. and Houénou, P.V. (2008). Etude analytique des caractéristiques chimiques d'un Lac eutrophe en milieu tropical : La conductivité comme indicateur de trophie du Lac de Buyo (Côte d'Ivoire). Journal de la Société Ouest-Africaine de Chimie,. 25: 87-108.

Ouattara, M. ; Doumbia, L. ; Yao, K. and Gourène, G. (2008). Reproduction du poisson-chat africain Schilbe mandibularis (Günther 1867) (Siluroidei; Schilbeidae) en milieux lacustre et fluviatile (Côte d'Ivoire). Livestock Research Rural Development, 20(1): 12.

Paugy, D.; Lévêque, C. and Teugels, G.G. (2003a). Faune des poissons d'eaux douces et saumâtres de l'Afrique de l'ouest. Tome 1. IRD, Paris, Musée Royal d'Afrique Centrale, 457 pp.

Paugy, D. ; Lévêque, C. and Teugels, G.G. (2003b). Faune des poissons d'eaux douces et saumâtres de l'Afrique de l'ouest. Tome 2. IRD, Paris, Musée Royal d'Afrique Centrale, 815 pp.

Pauly, D. (1979). Theory and management of tropical fisheries multispecies stock: a review with emphasis on the Southeast Asian demersal fisheries. ICLARM Studies Reviews, $1: 35$. 
Pauly, D. (1980). On the interrelationships between natural mortality, growth parameters, and mean environmental temperature in 175 fish stocks. Journal Du Conseil International Pour l'Exploration De La Mer, 39: 175-192. https://doi.org/10.1023/icesjms/39.2.175

Pauly, D. (1984). Fish population dynamics in tropical waters: a manual for use with programmable calculators (Vol 8). WorldFish.

Pauly, D. and Caddy, J.F. (1985). A modification of Bhattacharya's method for the analysis of mixtures of normal distributions. FAO Fisheries Circular (FAO). no. 781.

Pauly, D. and Munro, J.L. (1984). Once more on growth comparison of growth in fish and invertebrates. Fishbyte, 2: 1-21.

Tah, L. (2012). Exploitation du lac d'Ayamé I (Côte d'Ivoire) après le départ des pêcheurs «bozo»en 1998 et impact sur les structures démographiques des populations ichtyologiques. Thèse de Doctorat, Université Félix HouphouëtBoigny, Abidjan, Côte d'Ivoire, 177 pp.

Tah, L.; Joanny, T.G.; N'Douba, V.; Kouassi, N.J. and Moreau, J. (2010). Preliminary estimates of the population parameters of major fish species in Lake Ayamé I (Bia basin; Côte d'Ivoire). Journal of Applied Ichthyology, 26(1): 57-63. https://doi.org/10.1111/j.1439-0426.2009.01375.x

Ticheler, A. (2000). Conservation de la biodiversité des poissons dans les zones humides de l'Afrique de l'Ouest: plan d'action régional. Wetlands International, $36 \mathrm{pp}$.

Traoré, K. (1996). Etat des connaissances sur les pêcheries continentales ivoiriennes. Rapport de consultation. Projet FAO TCP/IVC/4553, IDESSA, Bouaké, Côte d'Ivoire, 93 pp.

Traoré, K.L. and Konan, L. (1989). Caractéristiques physico-chimique du lac de Buyo. Rapport IET, Abidjan, Côte d'Ivoire, 164 pp.

Vanga, A.F. (2001). Conséquences socio-économiques de la gestion des ressources naturelles : cas des pêcheries dans les lacs d'Ayamé et de Buyo (Côte d'Ivoire). Thèse de doctorat, Université d'Abobo-Adjamé, Côte d'Ivoire, 196 p.

Vanga, A.F. (2004). Conséquences socio-économiques de l'expulsion des pêcheurs étrangers en Côte d'Ivoire : lacs d'Ayamé et de Buyo. Revue Européenne Des Migrations Internationales, 20: 197-205.

Vanga, A.F. ; Gourène, G. and Ouattara, M. (2002). Impact de la pêche sur la disponibilité en poissons dans les régions des lacs d'Ayamé et Buyo (Côte d'Ivoire). Archives Scientifiques Centre de Recherche Océanologique d'Abidjan, 17(2) : 1-12.

Villanueva, M.C. (2004). Biodiversité et relations trophiques dans quelques milieux estuariens et lagunaires de l'Afrique de l'ouest: Adaptations aux pressions environnementales. PhD thesis, Institut National Polytechnique de Toulouse (INPT), France, 272 pp. 